\title{
NOT ANOTHER THING: \\ FOUR REFERENDUMS AND A BREXIT VOTE
}

James CONNELLY*

\section{Abstract}

Should we agree with Tom Peck that David Cameron was the "Worst Prime Minister in a Hundred Years?" (2016). Joseph Butler once stated that "Every thing is what it is, and not another thing" and that "Things and actions are what they are, and the consequences of them will be what they will be: why, then, should we desire to be deceived?" (Butler, 1841: Preface; 76). The United Kingdom (UK) is now faced with the claim that "Brexit means Brexit" a vacuous phrase which palpably begs the question at issue. For the issue is: what is Brexit? and what type of Brexit was voted for? To say that "Brexit means Brexit" is whistling in the dark as a means to ward off unwelcome spirits and to conjure up an appearance of resolve. This paper argues that the referendum on whether the UK should stay in the European Union was held by the then Prime Minister, David Cameron, to satisfy internal party critics and the campaign conducted in a manner inspired by his previous success in holding and winning referendums. Further, it argues that it has unleashed a new doctrine: that of the referendum result as an expression of the undiluted 'will of the people'. The holding of the referendum, its conduct and its result were direct results of complacency and hubris; what precisely a vote for Brexit means is unclear and ambiguous, and the populist belief that the result has to be upheld because it expresses the 'will of the people' is both cause and consequence of the referendum campaign and result. ${ }^{l}$

Keywords: Brexit, referendums, Conservative Party, will of the people, David Cameron, Harold Wilson.

\footnotetext{
* Professor of Political Theory, Department of Politics, University of Hull, e-mail: j.connelly@hull.ac.uk

1 I would like to thank Lord Norton of Louth for conducting an interview on the constitutional and political issues of the referendum.
} 


\section{BAŞKA BİR ŞEY DEĞİL: DÖRT REFERANDUM VE BİR BREXIT OYLAMASI}

\section{$\ddot{O} z$}

Tom Peck'in “Cameron'un yüzyılın en kötü başbakanı olduğu” görüşüne katılmall miyız? (2016). Joseph Butler, bir defasinda "Her şey neyse odur, başka bir şey değildir" ve "Şeyler ve eylemler neyse odur ve sonuçlarl ne olacaksa öyle olacaktır: Öyleyse kandırlmayı neden arzu etmekteyiz?" diye belirtmiştir (Butler, 1841: Preface; 76). Birleşik Krallık (BK) şimdi açıkca içi boş ve somut bir şekilde sorgulanmayl gerektiren "Brexit Brexit demektir" iddasıyla yüzleşmektedir. Çünkü bu Brexit nedir ve ne tip bir Brexit için oy verilmiştir meselesidir. "Brexit Brexittir" demek karanlikta istenmeyen varlıklardan korunmak ve çözümün zuhurunu çağırmak amaclyla ıslık çalmaktır. Bu makale, BK Avrupa Birliği'nde (AB) kalmalı mi diye soran referandumun, dönemin başbakanı David Cameron tarafindan parti içindeki eleştirel sesleri tatmin etmek icin yapıldiğını ve ilgili kampanyanın kendisinin daha önceki referandumlarl yapma ve kazanma başarısindan esinlenen bir tavirla yönetildiğini iddia etmektedir. Makale ayrıca, Brexit Referandumu'nun, referandum sonuçlarının 'halkın iradesinin' katıksız bir ifadesi olarak gören yeni bir doktrini ortaya salvverdiğini öne sürmektedir. Referandumun yapılması, yönetimi ve sonuçlarl, kendinden eminliğin ve kibrin doğrudan sonuçlar olmuştur. Brexit için oylamanın ne anlama geldiği belirsizdir ve sonuç 'halkın iradesi' olduğu için yerine getirilmelidir şeklindeki popülist inanç ise bu kampanyanin ve referandum sonucunun hem nedeni hem de neticesidir.

Anahtar Kelimeler: Brexit, referandumlar, Muhafazakar Parti, halkın iradesi, David Cameron, Harold Wilson.

\section{Introduction}

Every thing is what it is, and not another thing... Things and actions are what they are, and the consequences of them will be what they will be: why, then, should we desire to be deceived? (Butler, 1841: Preface; 76).

In what follows I shall argue, first, that Butler's comments apply in interestingly different ways both to Brexit and to the presumed similarity between the referendums of 1975, 2011, 2014 and 2016. Each referendum is the referendum it is, and not another referendum; generalising from one to another is imprudent and there is no transitive relationship in which victory in one leads inexorably to victory in its successor. To think otherwise is politically naïve and dangerous. Secondly, the Prime Minister, Theresa May, famously said that "Brexit is Brexit": but this only tells us that Brexit is not not Brexit; it does not 
tell us what Brexit is. That conundrum lies at the heart of the problem of Brexit and its antecedents. Brexit was an all consuming problem; the actuality of Brexit is an all consuming political diversion; and yet the referendum was supposed to be the remedy by which the problem of Europe would be solved, thereby freeing the Conservative government to focus on governing unhindered by mischievous backbenchers internally and the siren call of UKIP externally. One reason it did not is precisely that the Prime Minister who called the referendum, David Cameron, failed to realise both the differences between this referendum and previous referendums and that the question asked, while admirably clearly and binary in expression, nonetheless masked several distinct possibilities of the meaning of Brexit, were Brexit to be voted for.

There are those who argue that the Brexit referendum misrepresents what people in the UK really think and that there has never been a majority for leaving the European Union. That is not my argument: given the votes cast the leave side won and that is beyond dispute. It might be the case that, had more remainers seriously believed that membership of the EU was in doubt they would have turned out in greater numbers, and so on. But such conjectures are not to my purpose. My argument primarily concerns two issues. The first is to show that the Prime Minster, David Cameron, was misled both by the success of his predecessor, Harold Wilson, and his own previous success in holding and winning referendums, to believe that he could easily carry the referendum on the European Union too. His hubris led to the triple nemesis of his own defeat and resignation together with the uneasy recognition by the winners that they had to carry responsibility for what in some cases it appeared they had irresponsibly or frivolously willed. The second is to raise some concerns over the doctrine of the "will of the people" which has emerged in the wake of the referendum result and to show both that it is incoherent and that (notwithstanding the clear majority for Brexit) it is not clear what it is a majority for, and hence that the view that the referendum result contained a clear expression of the "will of the people" is inherently flawed.

\section{The Referendum Road}

There is no doubt that the 1975 referendum is in many ways directly comparable with that held in 2016. Each was led by a Prime Minister who sought to resolve problems largely internal to his own party by using the twin devise of renegotiation and referendum to do so (Saunders, 2016). There the similarity ends. The first resulted in a resounding victory (67\%-33\%) for staying in the European Economic Community and the latter clearly did not. Another important dissimilarity lies in the fact that in 1975 preparations were made to cover the possibility of leaving the EEC, during which it was revealed that this would already, after a membership of only two years, have been a matter of some difficulty, given the intertwining of domestic and EEC law and 
practice (Evans, 2018). The point to be noted is that the 1975 vote was an exemplar for David Cameron, an object lesson in party manipulation and political cunning. The problem was that he was deficient as a practitioners of both, unlike his master, and that he had misled himself, through earlier successes, into believing that he was an adept in these political arts.

In 2011 a referendum on the so-called Alternative Vote (AV) was held, which was won comfortably, with a vote of $68 \%$ in favour of the status quo and $32 \%$ against - proportions almost identical to that of Wilson's victory in 1975 . This referendum was a carefully choreographed piece of manipulation by the Conservative Party. Commitment to holding a referendum on electoral reform arose out of the coalition agreement with the Liberal Democrats following the 2010 general election. The resulting referendum offered a vote on electoral reform, but not a clear choice between the current single member plurality system and any of the proportional systems (such as the single transferable vote (STV), party list systems or a German-style mixed member system) which the Liberal Democrats might have favoured. On the contrary, the choice lay solely between Single Member Plurality (SMP) and AV. AV as a system offers minimal disruption to the current single member constituency ${ }^{2}$ system, and would have been easy and relatively non-disruptive to implement. Technically $\mathrm{AV}$ is a form of STV with district magnitude of one: in other words, it requires the winning candidate in each district to achieve at least $50 \%$ of the vote. If no candidate achieves $50 \%$ the least popular candidates are eliminated sequentially and their second preferences redistributed to the remaining candidates until a winner emerges. This system (known as preferential voting in other countries, such as Australia where it is currently used) has at least the merit of requiring a winning candidate to at least have a majority in their own district (unlike SMP where a winning candidate might have achieved only $25 \%$ or even less of the votes cast). However, it is not a proportional system on any definition of the term, and its results can frequently be, when aggregated nationwide, less proportional than the notoriously disproportional and almost random results typical of SMP.

The result of this forced choice was that those in favour of electoral reform were caught between the current unsatisfactory system and another system nearly as unsatisfactory. At best, AV could be construed, by the hopeful, as a change in principle opening up future possibilities for more serious electoral reform in the future. This was no accident: the referendum had been expressly designed by the Conservative Party to force the choice in this way. Given the choice, and given the ill informed and frequently mendacious campaign by the

\footnotetext{
2 The UK uses the term 'constituency'; however, the standard term in voting and electoral systems literature is 'district'. For details of the principles and workings of different electoral systems see Farrell (2010).
} 
government in favour of the current system, it is not surprising that the referendum resulted in a clear majority for retaining SMP. Here one might reasonably raise two issues: first, what choice should have been on offer? Secondly, how should a referendum designed to promote real and fair discussion of an appropriate electoral system have been structured? The answer to the first is that other alternatives, including open and closed party list systems, STV, and mixed member systems as well as AV should have been part of the discussion. The answer to the second is that ideally there should have been a two-part process consisting of an initial referendum on the principle of changing from the current system, and if there was a majority in favour of change, another referendum offering a clear choice between possible replacements for it. One might add that there should also have been appropriate safeguards such as a minimum level of turnout, or a defined supermajority. However, none of this obtained, the result being that a referendum was held which it was spuriously claimed had settled the issue of electoral reform for a generation, even though no real choice or proper debate had been held at all. The whole thing was a cynical piece of manipulation: but it was a well done and successful piece of political cynicism. But, as already stated, it is dangerous to assume that the lessons of one referendum are transitively applicable to a successor. So there were two consequences: first, that Cameron and his advisors were able to congratulate themselves on an excellent piece of political manipulation which secured the desired result; the second was that this success helped generate an element of hubris in the Prime Minister's thinking: after all, this referendum had been won as decisively and convincingly as had the 1975 referendum.

Next up was the 2014 referendum on Scottish independence. This was won by the unionist side by $54 \%-46 \%$. This referendum was going to happen at some point - pressure had been building for years. But throughout the campaign there was a great degree of complacency exhibited by the established UK-wide parties. The party most immediately vulnerable, in electoral terms, was the Labour Party as Scotland had for decades been a Labour stronghold. The irony is that although the referendum was won, at the election of 2015, the loss of many Labour seats to the SNP was a decisive factor in David Cameron unexpectedly winning the election with a narrow majority. Winning the referendum and the election the following year fed Cameron's hubris and generated complacency about his electoral abilities.

Although the unionist side won the referendum, the vote was tighter than many had supposed it would be: there was a narrowing of the gap in the final weeks, which created enough concern for political leaders from the major parties to scurry to Scotland to bolster the claims of the union. It is noteworthy that this last minute campaigning largely took the form of economic 
scaremongering, that is, raising concerns of how the Scottish economy would be adversely affected in the event of a vote for independence. It was an early example of what became known in the EU referendum campaign as "Project Fear." On this occasion it worked and waverers voted against taking risks. But the real lesson should have been that this referendum was rather tighter than that on AV, and that it cannot be presumed that what worked in Scotland is transferable to later referendums. In reflecting on this referendum is important to note that it was not possible to manipulate the question, choices and campaign as they had been (with laboratory-like precision) in the $\mathrm{AV}$ referendum. And there was a pre-existent and clear cut choice on an issue that people understood and were passionate about, partly in consequence of a palpable growth in support for independence as revealed in the performance of the Scottish National Party over a number of years. This contrasted sharply with the issue of electoral reform, where there was no clearly defined and concentrated groundswell of opinion, rendering it much more open to manipulation by those seeking to set the terms of the debate.

\section{The Final Path to Brexit}

Prime Ministers make history, but not always in conditions of their own choosing. In 2011 David Cameron, unusually, was operating in conditions of his own choosing and he exploited them with cynical and consummate ease. But each referendum is what it is and not another: and in the case of the EU referendum Cameron's position was weakened by his belief that the conditions were of his own choosing when palpably they were not.

Lord Norton's answer to the question of why was the referendum held was simple: there were political reasons and constitutional reasons. The political reasons were that it was held because it was a manifesto commitment arising from an attempt to satisfy the Eurosceptic wing of the Conservative Party. Initially Cameron was resisting a referendum and switched sides (Norton, 2015: 483-4). A key point is that the Conservative back bench business committee accepted holding a debate on a referendum on the EU. The number of Conservatives voting for this motion despite a three line whip tipped Cameron towards support. Cameron initially needed to keep his coalition partners (the Liberal Democrats) happy but the balance switched and he had to keep his own party happy - conceding the referendum was part of that.

The constitutional reasons were that a referendum was necessary because continued membership of the EU was a constitutional issue, even though the House of Lords had expressed concerns that "the threshold of what is considered a constitutional issue demanding a referendum is now too low (House of Lords, 2009-10: 2.3). Constitutional issues (rather than, for example, social issues) are the trigger for a referendum: but not all constitutional issues 
require a referendum. Although continuation is not necessarily a trigger, an issue such as leaving the EU, where there was a clear binary choice, was regarded as a constitutional issue (Norton 2017b).

Margot Wållstrom once commented that voters would always use referendums to answer a question that was not put to them: she was right. During the referendum campaign there was a widespread belief, shared by many, including the Prime Minister, that the remain side would win comfortably - as it had in 1975. Rafael Behr reports that former Labour staffers at Stronger In's headquarters resented the arrogance of Downing Street people, who thought they would easily repeat their victory in the general election of May 2015. One of them recalled that "They arrived like an occupying force", and that "they came in with a sense of, 'Step aside and we'll tell you how it's done"" (Behr, 2018). Cameron believed that he understood the context, and that it was, as it was always presumed to be, "about jobs and the economy and it won't even be close" (Behr, 2018). Further, Cameron's people were convinced that the campaign could be won using tactics advised by Lynton Crosby, who had concocted a winning strategy for the 2015 election: tactics included a mono-dimensional, focus on economic security and the risks of uncertainty (Behr, 2018).

Of course, a sceptic might interrupt here and suggest that, given that everyone thought that Remain would win, why should the Prime Minister be singled out for sharing that view? After all, even the Brexit side (including not only Nigel Farage, but probably Boris Johnson and Michael Gove) did not seem to think that it would win. Lord Norton, in answering whether he considered the result to be a surprise replied:

Yes it was - most people (and certainly the government) expected remain to win, although the margin of victory was expected to narrow in the weeks leading up to the referendum. There was an element of discounting the significance or accuracy of reports of significant support for leave. People interpreted things according to the result they wanted. It was seen as 1975 redux - there was an expectation that there would be a repeat. The so-called renegotiation (Wilson=Cameron) - did not amount to much but would give the outcome that we wanted. (Norton, 2017b)

But there were straws in the wind which had been spontaneously but inexorably gathering themselves into solid bales of EU scepticism over many years. This had not gone unnoticed. For example, Matt Qvortrup, argued in early 2016 that, based on statistical evidence from the previous 43 referendums held in Europe on EU matters, the opponents of EU membership would win the Brexit referendum (Qvortrup, 2016). Among other things, he analysed myths about referendums, one of which is that "voters are inherently sceptical and tend to vote no when given the opportunity" (2016: 61). As we have seen, this 
was resoundingly true of the referendum on electoral reform, and to a lesser degree of the referendum on Scottish independence. But, again, there is no transitive relationship. The old line, "if you don't know, vote no", was somehow transformed into "if you don't know, vote yes". In other words, those presumed to be risk averse either (according to one's view) voted for the riskier option because it was something in which they deeply believed, or refused to accept the political establishment's characterisation of which was the riskier option. The presumed context had done a $180^{\circ}$ turn, under the feet of the politicians who, because of the hubris generated by earlier successes were confidentially assuming they could repeat them and perhaps even emulate the master magician Harold Wilson's striking success of 1975.

Saunders remarks that "One of the more bruising comments on David Cameron's premiership is that it boils down to one recurring theme: 'doing what [Harold] Wilson did, only a little bit worse," and goes on to say that:

In the wake of the referendum, that verdict now looks generous. Like Cameron, Wilson was a reluctant European who led a divided party at a time of rising euroscepticism. Like Cameron, he pledged to renegotiate the terms of British membership and put them to the public in a referendum. The difference lies in the verdict. When the polls closed on 5 June 1975, Wilson had won a landslide for membership, winning more than two-thirds of the popular vote... By contrast, Cameron has presided over the biggest policy failure by a British government since the 1930s. The referendum has destroyed his premiership and set off an earthquake beneath British politics (Saunders, 2016: 318).

The problem, it might be said, is that it appears that one of the things that David Cameron did not learn either in studying politics at Oxford or practicing it at Westminster, is the truth of Max Weber's statement that "Politics means slow, strong drilling through hard boards, with a combination of passion and a sense of judgement" (Weber, 1994: 369). Instead, misled by false analogies from his previous successes, he succumbed to the hubris of believing in an easy fix.

Glencross argues that although Cameron blamed populism for his referendum defeat, a populism emerging from "a movement of unhappiness and concern about the state of the world", the responsibility was in fact largely his in that what made the claims about the merits and benefits of Brexit believable to leavers was "a politics of simple solutions promoted by Cameron" (Glencross, 2018: 22). This point can be further developed. The UK has been Eurosceptic throughout its entire membership of the EU and its predecessors (notwithstanding the 1975 referendum result), but the salience of the issue has generally been low, that is, until after the enlargement of 2004 which generated growing concerns about immigration. One key difference between the 1975 and 
2016 referendums is that attitudes to immigration signified very differently in each. In $2016,51 \%$ of those who believed there were too many immigrants to the UK, voted to leave the EU; only $11 \%$ of those holding the opposite view supported Brexit. In 1975 the difference was both far smaller (12 percentage points) and in the opposite direction (Evans and Menon, 2017: 14). This is interesting, given the way in which the issue came back to bite Cameron. In a speech on immigration in November 2014 he raised the stakes on immigration by saying that people "want government to have control over the numbers of people coming here". But ultimately Cameron did nothing to control numbers, and stuck to limiting eligibility for benefits instead. The result was both that "the Prime Minister had raised the stakes considerably ahead of negotiations with EU partners" (and created the language which was used by Brexiteers in the referendum campaign Evans and Menon, 2017: 22). In other words, he had forged the very weapons later used against him by his opponents. His approach to politics, by which he was able to cripple advocates of electoral reform, and to win the referendum on Scottish independence, resulted in a severe self-inflicted wound.

In Glencross's view, Cameron saw an in-out referendum on Europe as a "straightforward fix to internal Conservative Party strife over European integration" (2018: 22). When originally announced in early 2013, it seemed to be a low-risk option: at that time winning a single party parliamentary majority seemed unlikely and, besides, the prime minister was more concerned with dealing with his Eurosceptic backbenchers. However, two or so years later, one could understand why Cameron felt more entitled to "feel confident about his favoured political tactic of managing domestic challenges by forcing voters to choose between the status quo and an unknown future. He had already won two referendums on this basic premise, defeating supporters of the alternative vote (2011) as well as partisans of Scottish independence (2014)" (2018: 22).

But this referendum was different: each referendum, as we have argued, is different, whether protagonists notice it or not, and this was very different both from its immediate predecessors and from its great ancestor of 1975. In that referendum, by contrast with 2016 (where the only form of planning for an exit result which took place was a civil servants' away day held without the prime minister's knowledge) serious planning had taken place. The Foreign Affairs Committee dubbed this lack of preparation as "at best naïve and at worst negligent" (Evans and Menon, 2017: 93). Cameron's certainty, combined with his view that planning for an exit vote weakened the case for remain by accepting the possibility of the alternative, meant that the very thing required in the circumstances was the very thing not done. 
Lord Norton was asked whether there was a degree of complacency about the referendum because of the government's success in winning the 2011 and 2014 referendums. He answered:

Yes there was complacency and this was very important post-result: because there was no preparation. It might have made a difference in the campaign: the initial plan was to scare everyone and they will vote remain; when that didn't work there was not adaptability and no positive campaign - the remain campaign was not quick enough on the hoof. No mantra for remain side other than 'Better together'; 'Take back control' worked as a mantra and as a slogan. It is hard even to remember the Remain slogans (Norton, 2017b).

Further, Cameron had hobbled himself by claiming that he was going only to campaign in favour of remaining in the EU if he secured significant changes to EU treaties and that he would not start campaigning one way or another until the negotiations had finished. This thinly veiled political waffle convinced no one, least of all those deeply and longlastingly skeptical of the European Union: if anything, it reinforced their negative view of the machinations of the political classes. Cameron had gone so far as to say that he would lead the Out campaign if his renegotiation was unsuccessful. This raised the stakes again: the deal had to be good enough (or seen to be good enough) to turn him from a proclaimed Eurosceptic to a Europhile, at which point, and at which point only, he would campaign to remain.

The renegotiated terms of EU membership, announced in February 2016, failed to convince the sceptics. This was not a "reformed European Union" (and no one could seriously have expected it to be). In particular, there was a perceived failure to address concerns about controls over immigration and the rights of immigrants once resident in the UK. This issue had become highly salient, and it was something that the renegotiations were seen as scarcely touching. The result was both that Cameron was seen as being out of touch and that there was no clear and simple alternative to the simply stated message of the Brexit campaign: 'take back control'.

Glencross points out (as does Qvortrup) that political leaders should have taken notice of signs from previous referendums. Not the ones which they had manipulated and won, but others, such as those held in Europe on European integration. For example, the EU Constitutional Treaty had been rejected by two countries, effectively vetoing it; the Lisbon Treaty had been rejected by Irish voters; and the Greeks had rejected the bailout deal. Voters, even in countries rather less Eurosceptic than the UK, were reluctant simply to follow their presumed political masters and the elite political classes in moving towards greater European cooperation: why should the position be presumed to be more favourable to the EU in the UK? 
How and why did Cameron get into this position? One reason is that it was not just external pressure that pushed him towards holding a referendum. There was internal pressure too: he wanted to deal with the Eurosceptic wing of the Conservative Party which had been (and continued to be a pain in his side). In August 2014 Douglas Carswell triggered a by-election in Clacton on Sea by defecting to UKIP, and in September Mark Reckless joined UKIP and triggered a by-election in Rochester and Strood. Both by-elections were won by UKIP with large majorities; leading to intensified peculation about who and how many Conservative MPs might defect. Pressure from the electoral success of UKIP was real. Their tactic of conflating anti-immigration feelings with hostility to the EU had led to its victory in the 2014 European Parliament elections. This was an historical first: UKIP won the elections with $27.5 \%$ of the vote: this was the first time since the First World War that neither Labour nor Conservatives had won a national election.

One issue was that, as we have seen, the remain side failed to see that the issue was a deep one, residing in the psyche and emotions of the British people, and their sense of values. This mean that they were responsive to certain sorts of appeals and slogans, but not those provided by the pro-EU camp, which were, at best, lacklustre and weak. This is why Tim Haughton argues that "the reason why the United Kingdom voted to leave the European Union can be expressed in three words: "Take Back Control"' (Haughton, 2016). The Leave side used this slogan constantly and, by contrast, the Remain side never came up with a comparably simple and effective slogan. Of course the slogan was vague, and reflected an inadequate sense of how the EU and its institutions work: but it combined a sense of a positive future with a sense of rightful ownership. Further, it helped to mobilize the anti-establishment support of voters who felt that the political class had failed them. Thus the referendum became a vote not only on the EU but on the competence and trustworthiness of the established political class in general: "frustrated by the sense that the political class had failed them, many ordinary citizens took the opportunity to vent their fury' (Haughton, 2016).

It is worth noting that the official Leave campaign was run by Matthew Elliott who had headed the No to $A V$ campaign in 2011 and that he used similar tactics in 2016: "so, while Remain focused on facts, even at the cost of running a rather dry and emotionless campaign, their adversaries adopted a more visceral approach. And this was true even at the level of slogans, where 'Stronger, Better off and Safer in Europe' proved no match for 'Take Back Control' or 'Be Leave"' (Evans and Menon, 2017: 58). In addition, the leave campaign, assuming the inevitability of their victory, failed to take action to secure that victory. For example, David Cameron was focused on reuniting the Conservative Party after the referendum. Hence a poster showing Boris Johnson 
in Nigel Farage's pocket (modelled on one showing Miliband in Salmond's pocket in the 2015 UK general election) was not deployed. Elliott states that had the Remain campaign use the poster it might have swung the vote (Evans and Menon, 2017: 64).

Earlier the point was made that the referendum on electoral reform was, for various reasons, inadequate to the task both of ensuring an intelligent debate and a meaningful vote because of its failure to properly lay out the different options in the proper order which would have allowed an informed choice to be made. In 2011 this was both deliberate and successful, and a vote for change would have been straightforward to implement. There was both a binary choice and a clearly implementable answer in both eventualities. In the 2016 referendum there were parallel issues, the key difference being that whatever the merits of a vote in either direction, the apparently simple binary choice of remaining or leaving concealed enormous and potentially treacherous ambiguities. Although it can be argued that remaining in the EU had its own uncertainties, at least a vote to remain was clear and unitary. The same cannot be said for a vote to leave, because the question as posed in the referendum ignored what it meant to leave and on what terms.

Lord Norton argues that the question was clear, offered a binary choice, and avoided ambiguity (Norton, 2017b). He is not wrong: the question is clear. But the choices and their consequences were not clear; and if there were a vote to leave, this would begin to matter a great deal. A vote for leave was an indeterminate vote for one of at least three different and incompatible options. The first was to terminate full EU membership but remain within the single market. This is the "Norway Model" and would be the least disruptive to trade relations with the EU. But it would mean being subject to EU law, and continuing to accept freedom of movement and paying into the EU budget. The second was to leave the single market and customs union and to negotiate a bilateral trade deal with the EU. The third option would be to rely on WTO rules to govern bilateral trade with the EU. This is the option now familiarly known as "Hard Brexit" and it is the option which would have the greatest economic impact. Thus there was indeed a clear binary choice on one level; at another level this binary appearance masked four discrete outcomes. Those who voted yes knew what they were going to get; those who voted no didn't know.

It was noted earlier that referendums are reserved for constitutional issues. On such issues it is reasonable to ask whether there should have been safeguards in the form of thresholds relating to turnout or the required majority. In answer to this question, Lord Norton pointed out that he had indeed himself raised the issue of thresholds when the referendum bill was going through parliament. He has principled objections to the use of referendums, but given that referendums are a feature of the political landscape, the issue now is not 
whether, but how are they to be run. One part of the answer is the use of thresholds, and the possibilities include, for example, stipulating that a majority should constitute at least $50 \%$ of eligible voters and/or the use of a supermajority. In his view a supermajority is probably better as it is less reliant on data and avoids the possibility of the system being gamed by devices such as encouraging people not to vote to ensure a low turnout. However, when Norton raised the issue, the reaction from the two frontbenches was not encouraging there was no enthusiasm for any such proposal. Once Labour had conceded the case for holding the referendum they showed no interest in the details of the referendum itself. A proper debate should have focused on the referendum process itself, not on the benefits or otherwise of EU membership, but the majority of the most vocal contributors were those with a strong interest in leaving or staying. Hence in the debate on the provisions of the bill most speakers were not concerned with the substance of the bill and the appropriateness of the processes and were more concerned with EU membership itself. Further:

There was a considerable degree of complacency: there was an element of "going through the motions". There was a debate but an underlying assumption that there would be a majority for remain. The government was not prepared to concede that a leave vote might win. Introducing provisions such as supermajorities etc would have been to have conceded that a leave vote might win: so stuck with simple majority. And that is also why the referendum was advisory and not binding. The AV referendum was binding and this one could have been binding. But had it been made binding that would have been to concede that the leave vote might win (Norton, 2017b).

Norton's final conclusion is that although the referendum is not legally binding it is politically binding.

\section{A New Doctrine of the Mandate: Brexit and "the will of the people"}

A spectre is haunting British politics - and perhaps politics worldwide: the doctrine of the "will of the people". This is a new form of mandate, trumping expertise, trumping judgement, suspicious of representative and parliamentary representation. It constitutes a preference for direct democracy as expressing the will of the people. The mandate is both very precise and extremely vague and empowers leaders to use it as they wish. Suspicion of the political classes, which underlies this new doctrine, leads to a distrust of representatives, which is replaced by trust in leaders guided by the mandate which consequently becomes a general justification of any action.

Vernon Bogdanor, the Oxford don who taught David Cameron as an undergraduate, has argued that there is now a new principle in the British constitution: "the principle of the sovereignty of the people, a principle which, 
in some respects, supersedes the sovereignty of Parliament" (Bogdanor, 2016: 318 ) and that this was introduced into national politics in 1975 to resolve the European issue. He claims that:

The referendum has now established itself as a third chamber of Parliament, issuing legislative instructions to the other two. The sovereignty of the people is trumping the sovereignty of Parliament. The Commons is required, perhaps for the first time in its history, to follow a policy to which around three quarters of MPs are opposed. The sovereignty of Parliament is now to be con- strained - not legally, of course, but for all practical purposes - not by Brussels but by the people (Bogdanor, 2016: 350).

Bogdanor's view is not uncontested. ${ }^{3}$ However, the notion of the will of the people has considerable rhetorical and political resonance, whether it is a new constitutional principle or not. And the point about populist slogans is that they are no respecters of political niceties.

One interesting discussion is provided by those who, like Shaw, argue that we should consider whether there is now more than one demos at work in the British context; rather, we should think of different demoi differentiated by geography, different citizenship rights and practices. This is important considering that Northern Ireland and Scotland and London, for example, all voted clearly in favour of remain. A referendum gives a clear national aggregate outcome - but in conditions where precisely such an aggregate can be seen as ignoring key features of contemporary political reality which need to be taken into account in a thorough theory of representation. At the very least, the existence of these different demoi casts doubt on the interpretation of the result as expressing a single unified "will of the people."

For many there was an impression that, unlike general elections where whoever one voted for the political classes still won, the Referendum provided a real choice. On this view, "It was one of those rare occasions when people voted in numbers and with conviction on a major question of policy they had the power to decide on. This was democracy as many believe it should be" (Evans and Menon, 2017: 123). The problem is that this view represents both a repudiation of the principles of representative democracy and a view that sovereignty not only lies with the people, but that it can be expressed through referendums, taken to be authoritative statements of the will of the people, irrespective of the vote or majority or any form of constitutional check or arrest. The idea is that a referendum result uniquely expresses the will of the people and does so existentially in a way that cannot be gainsaid by mere attention to votes, majorities, level of turnout or the like. And its roots in a dubious reading 
of Jean Jacques Rousseau are likewise ignored: the people have spoken and the will of (some of the) all has become the general will or the will of the people. The will of the majority who voted no in the referendum is taken to represent the will of the people: so much so that May referred to "The strength and support of 65 million people willing us to make it happen" in her Lancaster House speech of January 2017 (Shaw, 2017: 2). Not only does it deny the rights of parliament and the functioning of parliamentary democracy, replacing it with the "will of the people", it identifies the "will of the people" with that of a small minority of the British population. Further, by synecdoche, this "will" is then both descriptively and normatively attributed to the population as a whole, who are presumed either to adhere to it, or admonished for perceived failure to adhere to it. Of course, in one way, after every national vote, whether in an election or a referendum, there arises much glib talk of what the "British people" have decided as though the "British people" were a reified entity voting as one: but this has been taken a step further in the post Brexit referendum rhetoric.

The problem is this: it is perfectly in order to refer to the "winners" of a referendum: but to claim that because it is somehow the "will of the people" and therefore that all further debate on the point at issue should be stifled is quite another thing. And that is what is happening currently: but a liberal democracy is not a winner takes all form of government: it is both representative and liberal; the winners are not presumed to have absolute power or that all opposition will cease. The claim of the referendum as an appropriate vehicle for determining the prevalent view on this particular question is not the issue here; but the claim that the "will of the people" should override the constitutional and representative democratic principles of a liberal democracy is a dangerous development in which all questioning of means, processes and precise choice of outcomes is branded as disloyalty and treacherous opposition.

\section{Conclusion}

One of the curious things about the 2016 referendum result was that there was a triple nemesis: Cameron lost the vote and resigned; but Gove and Johnson, other Brexiters, and the government were all left with a result they didn't know how to handle and Theresa May took on the burden of honouring a result she hadn't willed. As if to mock her further, May's attempt to improve her electoral position by holding an early general election in 2017 was met, humiliatingly, by the loss of her majority and the nemesis of having to enter into an unprincipled alliance with the Ulster Unionists.

It had seemed to many, and especially to the prime minister, that a vote to remain was secure. As we have seen, this was by analogy with the referendums held in 1975, 2011 and 2014. But what David Cameron failed to realise was 
that each of these referendums had changed the political landscape and that much political water has flowed in the forty years since Harold Wilson pioneered the art of using national referendums as solutions to party problems. Perhaps the lesson to draw is that this trick can only work once and that to copy is to fail. Less self confident Prime Ministers, less certain of themselves and their abilities to control the political weather might have been more circumspect. But Cameron's confidence had been fed and watered by his experience of the two preceding referendums over which he had presided and by the belief that he could do in 2016 what Wilson had done in 1975 . But the differences were decisive: Wilson was a canny political operator who, although he called the referendum primarily to keep his own party in order, was able to stand above the fray and be the moderator. Cameron was not as canny as he believed himself to be, and he had manoeuvred himself into a position in which it was impossible for him to conduct the referendum as a convincing advocate of his own position; and he fatally failed to recognise that the circumstances were changed beyond compare. A sequence of successful referendums does predetermine the outcome of the latest. On the contrary, together with a widespread perception that the British political classes had ceased to listen to the British public, it had created the possibilities for revolt and the expression of cynicism or scepticism towards not only the EU but also whatever it was felt that a vote to remain in the EU represented.

The AV referendum of 2011 had been conducted like a laboratory experiment in which a particular result was deliberately engineered. The essential but tacit advantage possessed by the proponents of the status quo then was a combination of ignorance and indifference on the part of the voters: victory required it to remain intact. But the Scottish independence referendum could not be controlled in that way, and the result was a considerable relief to the unionist; and in the EU referendum the experiment took place outside the laboratory, control was entirely lost, and ironically, the campaign was won by the side whose slogan was "take back control." If Harold Wilson was the sorcerer and David Cameron the apprentice, putting the apprentice in charge of the laboratory was a serious mistake. The apprentice mistakenly believed that his control over the earlier referendums meant that he could control the greater forces at work in the EU referendum. He was sadly mistaken. By seeking to emulate both his own past successes and Wilson's success, Cameron merely directed greater attention to his own failure and revealed why the sorcerer Wilson is now held in increasingly high regard. This fate is unlikely will overtake Cameron in the near or the far future. The way Cameron conducted his politics both inadvertently created the conditions for his own failure and altered the political landscape: a change which it will take a long time to recover from. In the words of Glencross, 
the appeal to the sovereign people cannot be a replacement for representative democracy, because a government is still required to exercise sovereignty in the aftermath of any referendum. Nowhere is this more obvious than in the case of the UK following the vote on 23 June 2016. British politicians ... have had to face the consequences that stem from unilateral attempts to resolve complex problems of European interdependence. Cameron's habit of ruling via easy fixes will have a lasting national impact because it leaves those in power at Westminster and Holyrood at the mercy of the same forces that cost him his job (Glencross, 2018: 26).

The fixes could not work because the context had changed and Cameron was found wanting. Norton contrasts Cameron interestingly with John Major, dealing with eurosceptics in the early 1990s:

[Major's] willingness to stick to his position, despite a precarious - and a times non-existent parliamentary majority, and attacks by his predecessor and her allies, stands now in contrast with the stance taken by his successor as Conservative Prime Minister, David Cameron. Cameron had negotiated a coalition in 2010 in order to produce a parliamentary, but had to walk a tightrope between the stance of his coalition partners and his own backbenchers. He conceded a referendum on introducing a new electoral system as part of the deal to create a coalition. After initially resisting demands of Eurosceptic backbenchers, he eventually succumbed and promised a referendum on the UK's membership of the European Union. He sought to renegotiate Britain's terms of membership, in so doing adopting a more self-confident approach than that adopted by Major, but one that failed to deliver what he expected of it. Whereas Major by his actions had managed to keep the UK in the EC, at the risk of splitting his own party, Cameron let party considerations dictate an approach that was to result in a referendum voted in 2016 to leave the EU (Norton, 2017a: 83-4).

So what have we learned? In brief, that a referendum is the referendum it is and not another, and that Brexit is not what it is (whatever that is) but merely the possibility of a number of things, concealed in open view by the phrase 'Brexit is Brexit'. Actions are what they are, and their consequences will be what they will be, but whether anyone intended these consequences is quite another thing. Finally, David Cameron thought he controlled the context, but he did not, and the context became his master and he its slave: "Cameron thought he could wing it on the basis of previous success. The AV referendum majority was like 1975. And even in the Scottish referendum (despite a big scare towards the end) the result was decisive: $54 \%-46 \%$. The scare might have emboldened Cameron: that is, ignore the scare we'll still win; we won't countenance a leave vote. And then: Whoops! what happens now?" (Norton, 2017b). 
During the referendum campaign both sides were perceived to be exaggerating and over-claiming (whether positively or negatively). This bred cynicism and disbelief and led many people to fall back on their long-held views and values. The whole political class, including politicians and experts of all shapes and sizes were tarred with the same brush and disbelieved en masse. Worse, for the remain campaign, the mainstream was seen as having something to hide. In such conditions two things happen - the first is to fall back on longheld views, beliefs and values; the second is that, in the absence of epistemic trust it becomes rational to choose capriciously, and to invest one's hopes in charismatic leaders and policies which can be taken as belonging to oneself and not the despised political classes whose self-enclosed bubble of certainties one wishes to burst. Distrust of both sides looked symmetrical but had an asymmetrical outcome.

Labour politician Roy Jenkins said of the 1975 referendum that it was a result of the electorate taking the advice of people they were used to following. David Cameron appears not to have understood quite how far things had changed over time. Hence following Wilson's precedent was doomed to failure, precisely because it was no precedent at all: the superficial similarities masked deeper differences which had been developing over many years. 


\section{References:}

Behr, R. (2018) "How remain failed: the inside story of a doomed campaign", The Guardian 21/2/18, <https:/www.theguardian.com/politics/2016/jul/ 05/how-remain-failed-inside-story-doomed-campaign>, (21 February 2018).

Bogdanor, V. (2016) "Europe and the Sovereignty of the People", Political Quarterly, 87(3): 348-51.

Butler, J. (1841) Fifteen Sermons, (London: Tegg).

Evans, A. (2018) "Planning for Brexit: the Case of the 1975 Referendum", Political Quarterly, 89 (1): 127-33.

Evans, G and Menon, A. (2017) Brexit and British Politics, (Cambridge: Polity Press).

Farrell, D. (2010) Electoral Systems: a Comparative Introduction (second edition), (London: Palgrave Macmillan).

Glencross, A. (2018) “Cameron's European legacy: How Brexit demonstrates the flawed politics of simple solutions," in B. Martill and U. Staiger (eds.), Brexit and Beyond: Rethinking the Futures of Europe, (London UCL Press), pp: $22-7$.

Haughton, T. (2016) "It's the slogan, stupid: the Brexit referendum", $<$ https://www.birmingham.ac.uk/research/perspective/eu-refhaughton.aspx>, (20 December 2017).

House of Lords (2010) Referendums in the United Kingdom, Select Committee on the Constitution, $12^{\text {th }}$ Report of Session 2009-10.

Mabbett, D. (2017) "Parliamentary sovereignty and Brexit", Political Quarterly, 88 (2): 167-9.

Martill, B and Staiger, U. (eds) (2018). Brexit and Beyond: Rethinking the Futures of Europe, (London: UCL Press).

Norton, P. (2015) "The Coalition and the Conservatives" in A. Seldon and M. Finn (eds) The Coalition Effect: 2010-2015, (Oxford: Oxford University Press), pp: 467-91.

Norton, P. (2016) Why was there a referendum? The Norton View, 24/6/2016. $<$ https://nortonview.wordpress.com/2016/06/24/why-was-there-areferendum/>, (19 December 2017).

Norton, P. (2017a) "The Constitution", in K. Hickson and B. Williams (eds.), John Major: An Unsuccessful Prime Minister? Reappraising John Major, (London: Biteback), pp: 73-89. 
Peck, T. (2016) "Goodbye David Cameron: the worst prime minister in a hundred years", The Independent, Friday 24 June 2016, $<$ http://www.independent.co.uk/news/uk/politics/goodbye-david-cameronthe-worst-prime-minister-in-a-hundred-years-a 7100746.html>,

(13 September 2016).

Qvortrup, M. (2016) "Referendums on membership and European integration 1972-2015”, Political Quarterly, 87 (1): 61-8.

Saunders, R. (2016) “A tale of two referendums: 1975 and 2016”, Political Quarterly, 87 (3): 318-22.

Shaw, J. (2017) "The quintessentially democratic act? Democracy, political community and citizenship in and after the UK's EU referendum," Journal of European Integration, 39(5): 559-74.

Weber, M. (1994) "The Profession and Vocation of Politics" in P. Lassman and R. Speirs (eds.), Weber: Political Writings, (Cambridge: Cambridge University Press), pp: 309-369.

\section{Interview}

Norton, P. (2017b) Interview with Philip, Lord Norton of Louth, November $10^{\text {th }}$ 2017. Lord Norton is Professor of Politics at the University of Hull and a sitting member of the House of Lords, to which he was elevated in 1997. 